\title{
ORIGEM E TRANSFORMAÇÃO DOS NÚCLEOS URBANOS DAS CIDADES DE MARTINÓPOLIS E INDIANA.
}

Mariana Guimarães Marchezi Chaves, Arlete Maria Francisco

Universidade Estadual Paulista - UNESP, Curso Arquitetura e Urbanismo, Presidente Prudente, São Paulo. E-mail: maariana chaves@hotmail.com.

Agência de fomento: CNPq.

\section{RESUMO}

O transporte ferroviário foi indutor do desenvolvimento do país e da urbanização de algumas cidades. Na região da Alta Sorocabana, a ferrovia deu origem aos núcleos urbanos, a partir das estações. Esta pesquisa estudou duas cidades, Martinópolis e Indiana, que apresentam características comuns em sua formação. O objetivo foi realizar a análise morfológica das cidades e investigar a origem dos núcleos urbanos. A metodologia constou no estudo do tecido urbano e seus elementos formadores, utilizando bibliografia e documentação disponível sobre as cidades e trabalho de campo. $O$ traçado foi redesenhado em AutoCad, e assim as leituras foram feitas. 0 desenho urbano obedeceu ao tabuleiro de xadrez e se organizou a partir da estação. Observou-se que não havia preocupação estética e urbanística nos desenhos dos núcleos urbanos. As modificações mais significativas foram a ocupação da esplanada e a destruição de edifícios ferroviários, sendo o traçado o elemento que menos se modificou.

Palavras-chave: Desenho Urbano, Estrada de Ferro Sorocabana, Martinópolis, Indiana.

\section{ORIGIN AND TRANSFORMATION OF THE URBAN CORE OF MARTINÓPOLIS AND INDIANA CITIES.}

\begin{abstract}
The railway transport was inductor of the country's development and the urbanization of some cities. In the region of Alta Sorocabana, the railway gave rise to urban cores from its stations. This research studied two cities, Martinópolis and Indiana, which have common characteristics in its formation. The aim was to accomplish morphological analysis of the cities and investigate the origin of their urban cores. The methodology was to study the urban tissue and its forming elements, using bibliography and documentation available about the cities and fieldwork. The layout was redesigned in AutoCad, and then the readings were accomplished. The urban design followed the standard in chessboard and was organized from the station. It was observed that there was no aesthetics and urban concern about the design in urban cores. The most significant modifications were the esplanade occupation and destruction of railway buildings, the layout was the element that less changed.
\end{abstract}

Keywords: Urban Design, Sorocabana Railway, Martinópolis, Indiana. 
O transporte ferroviário desempenhou papel importante como desbravador e indutor do desenvolvimento econômico do país e do processo de urbanização das cidades por onde os trilhos passavam. No estado de São Paulo, as ferrovias chegaram na década de 1860, com a expansão da fronteira agrícola no estado e a demanda crescente por transportes que escoassem a produção cafeeira, os trilhos foram expandidos para o interior, novas empresas ferroviárias foram constituídas, e assim surgiu a Estrada de Ferro Sorocabana, que além de escoar os produtos e transportar a população, também possibilitou a integração dos núcleos já existentes e a formação de novos, e foi o meio usado pelos negociantes de terra para levarem seus compradores a conhecer as glebas, favorecendo a ocupação. Desta maneira, a Estrada de Ferro Sorocabana foi um dos principais elementos responsáveis pela ocupação do Oeste Paulista em conjunto com a introdução da cultura do café (Abreu, 1972; Francisco, 2015).

Na região da Alta Sorocabana, a implantação dos trilhos deu origem aos núcleos urbanos, a partir das suas estações. Esta pesquisa se propôs a realizar o estudo de duas destas cidades, Martinópolis e Indiana, que surgiram a partir da expansão da Estrada de Ferro Sorocabana para o Oeste Paulista, as quais apresentam características comuns em seu processo de formação urbana.

O objetivo deste estudo foi realizar a análise morfológica das cidades e investigar a origem dos seus núcleos urbanos. Como objetivos específicos, identificar os autores da produção do núcleo urbano e as transformações ocorridas nos traçados originais; sistematizar o conjunto de informações iconográficas e documentais dos traçados originais das cidades.

\section{METODOLOGIA}

A pesquisa se desenvolveu a partir do método de análise morfológica, baseado em Lamas (1993) e Panerai (2006). A morfologia urbana estuda o tecido urbano e seus elementos formadores, e compreende a lógica de formação e mudança da cidade no tempo. Esse estudo é feito através da análise do crescimento, do traçado e parcelamento, da tipologia dos elementos urbanos e das relações entre eles.

Para tanto, utilizou-se bibliografia disponível sobre as cidades em estudo e sobre a ocupação do Oeste Paulista; documentação disponível no Arquivo Público do Estado, no Instituto Geográfico e Cartográfico e no Escritório da Inventariança da Rede Ferroviária Federal S.A. em São Paulo e trabalho de campo.

Do ponto de vista metodológico, a análise foi feita através do estudo dos mapas da cidade, observando o crescimento, o traçado, o parcelamento, os outros elementos morfológicos e a relação entre eles, além de esquemas gráficos.

\section{RESULTADOS}

Em Martinópolis, a estação de trem foi inaugurada em 05 de agosto de 1917, e levou o nome de José Teodoro (Quadro 1). Durante seus primeiros anos, até 1924, a estação tinha pouco movimento. É nesse mesmo ano que surge a figura do Coronel João Gomes Martins, que dividiu as terras da região e lançou o loteamento urbano em apenas um lado da ferrovia e, dessa forma, começaram a surgir as primeiras residências e comércios.

Após adquirir a propriedade das terras, o colonizador contratou um engenheiro, Mário Cabral, e um agrimensor, Alberto Amaral, para projetar o loteamento, e assim o núcleo urbano começou a ganhar forma. Foi feito o arruamento com quadras de $80 \times 80$ metros, quinze ruas e três avenidas (Daltozo, 1999).

A partir de análise dos mapas antigos encontrados deduziu-se qual seria o perímetro original (Figura 1), e constatou-se que o desenho do núcleo urbano é em forma de tabuleiro xadrez. Observou-se que uma das avenidas está descolada em relação ao eixo perpendicular da estação, mas a rua em que chega a estrada de acesso a cidade prolonga-se até ela. 


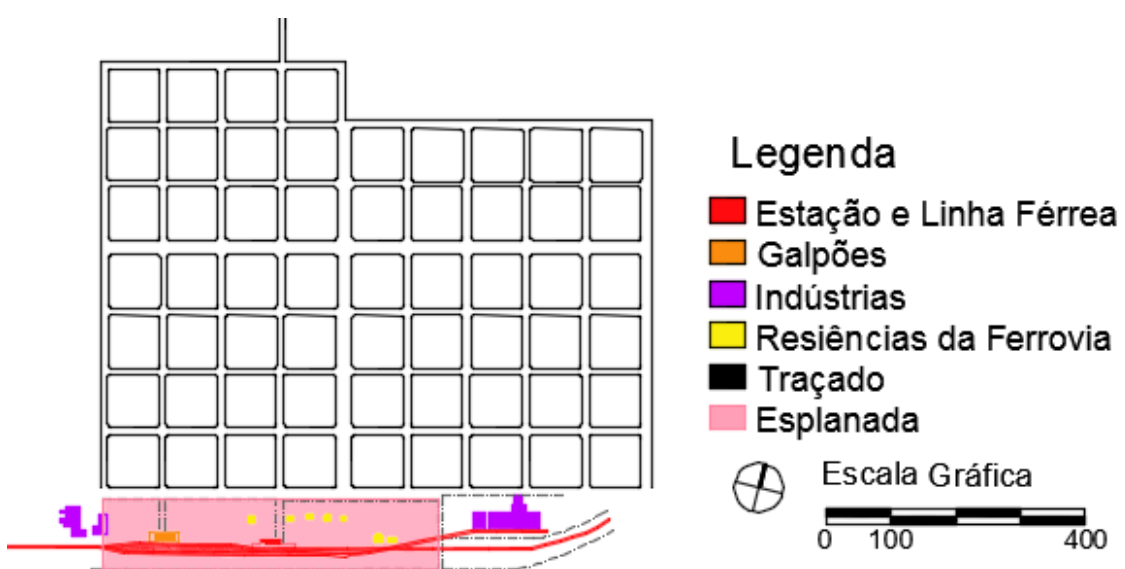

Figura 01. Núcleo Urbano Original de Martinópolis, 1927.

Fonte: Arquivo Público do Estado de São Paulo e Daltozo (1999), redesenhado pela Autora.

A cidade procurou repetir essa malha ortogonal em tabuleiro de xadrez em seu crescimento, observado através do padrão que se mantém no entorno da área do núcleo urbano original, mas em suas expansões mais recentes, há uma mudança nesse desenho, observa-se que traçado se modifica nos pontos mais distantes da área central (Figura 2).

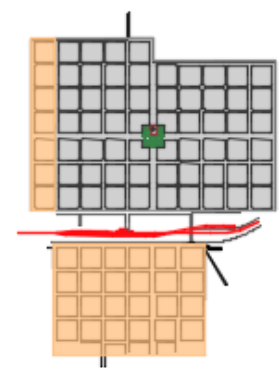

Expansão até 1939

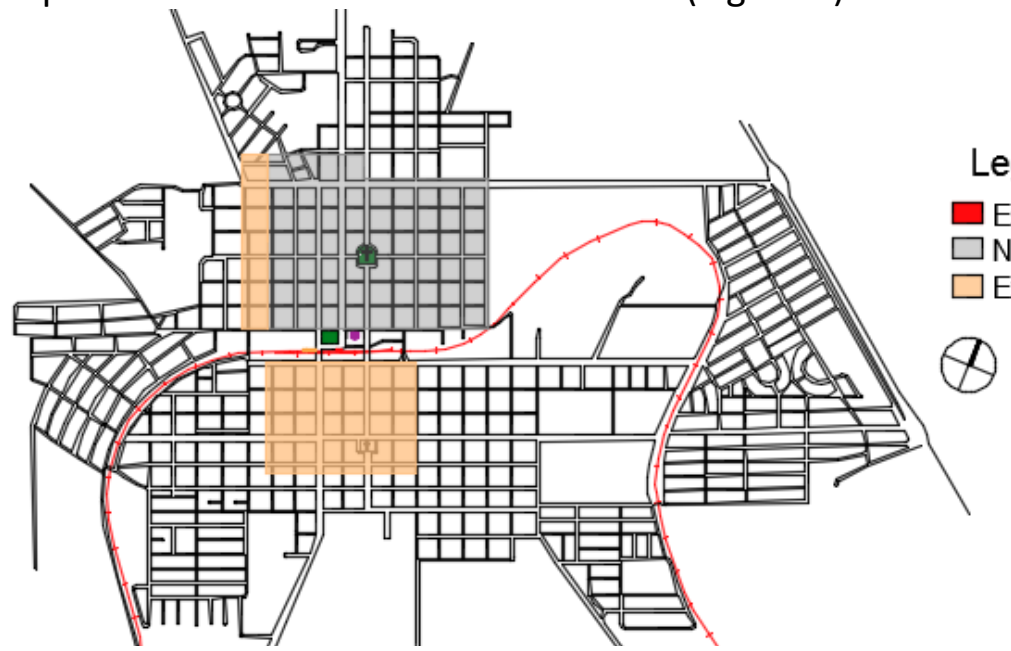

Legenda

Estação e Linha Férrea $\square$ Núcleo Urbano Original $\square$ Expansão

\section{Escala Gráfica} $0 \longdiv { 1 0 0 } 5 0 0$

Figura 02. Esquema de Crescimento de Martinópolis.

Fonte: Arquivo Público do Estado, Daltozo (1999) e Google Earth, redesenhado pela Autora.

As estações localizavam-se junto a esplanada que constituem uma grande área plana, com formato de retângulo alongado, que variava nas dimensões conforme a cidade. O tamanho garantiria espaço para localização de outras construções da ferrovia, como casa de funcionários, depósitos e ampliações. A frente da estação era deixado um amplo espaço para estacionamento, embarque e desembarque de passageiros, e carga e descarga de mercadorias.

A esplanada da Estação de Martinópolis era ocupada inicialmente pelas residências de funcionários da ferrovia e dois galpões da companhia Estrada de Ferro Sorocabana (Figura 3). 


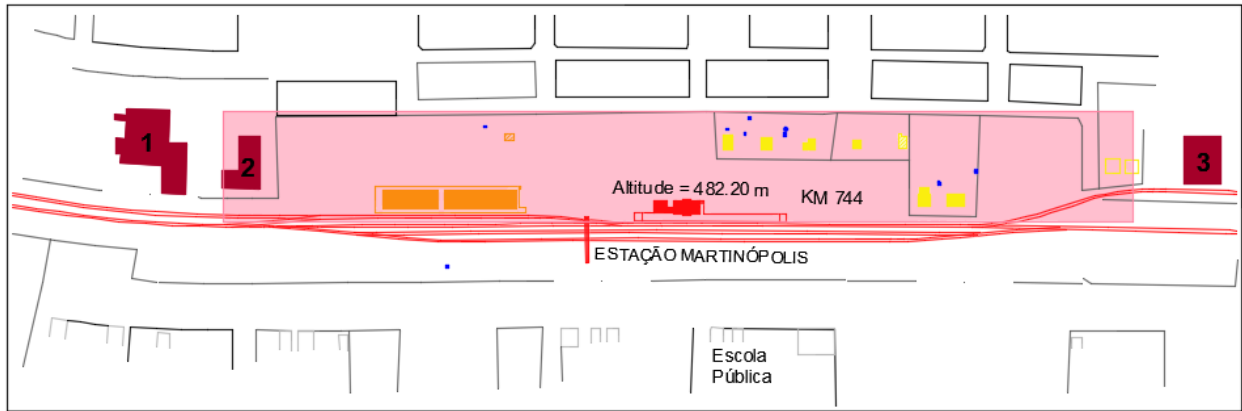

Figura 03. Mapa da Esplanada de Martinópolis, ano desconhecido.
Legenda

$\square$ Estação e Linha Férrea

$\square$ Galpões

$\square$ Residências da Ferrovia

$\square$ Indústrias

1. Serraria

2. Máquina de Beneficiar Café

3. Barracão

Instalações Hidráulicas

$\square$ Esplanada Original

- Traçado

(1) Fonte: Escritório da Inventariança da Rede Ferroviária Federal S.A. de São Paulo, redesenhado pela Autora.

Atualmente, a esplanada da Estação está ocupada por uma praça, denominada Praça Getúlio Vargas, e por algumas residências de funcionários do antigo pátio (Figura 4), cinco permaneceram como residências de ferroviários aposentados, enquanto as outras servem para atividades administrativas e culturais.

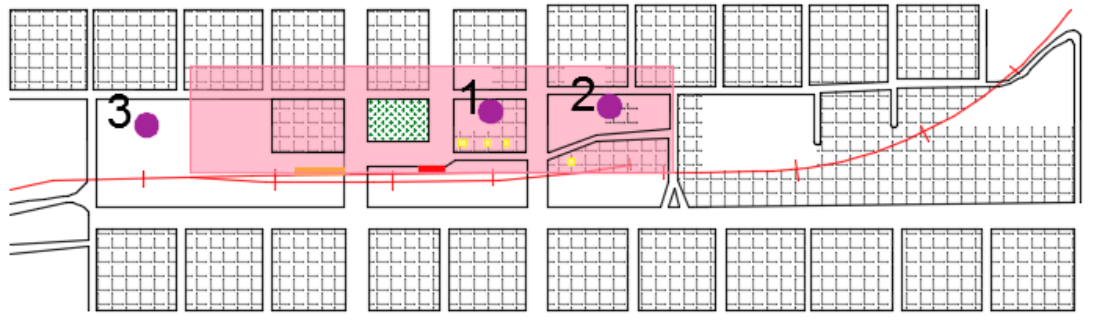

Legenda

$\square$ Estação e Linha Férrea

$\square$ Galpões

- Traçado

$\square$ Residência da Ferrovia

Praça

- Edifícios Públicos

1. Prefeitura

2. Rodoviária

3. Ginásio de Esportes

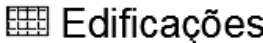

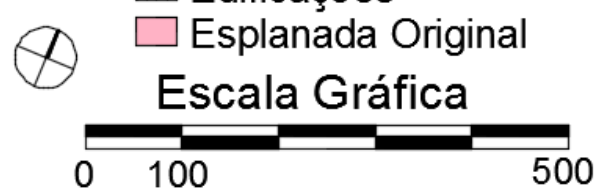

Figura 04. Mapa da Esplanada de Martinópolis atualmente. Fonte: Google Earth, redesenhado pela Autora.

A estação foi restaurada e hoje abriga o Banco do Povo, um posto do Sebrae, um minimuseu e alguns departamentos da prefeitura. Os dois antigos armazéns, situados ao lado da estação, são ocupados por projetos culturais e educacionais.

As transformações visuais que ocorreram ao longo do tempo em Martinópolis não foram tão marcantes, como percebe-se nas comparações de algumas das ruas da cidade (Figuras 5 e 6 ). Poucas alterações aconteceram, apenas algumas edificações, detalhes nas fachadas e a pavimentação foram modificadas, o aspecto desses locais pouco mudou. 

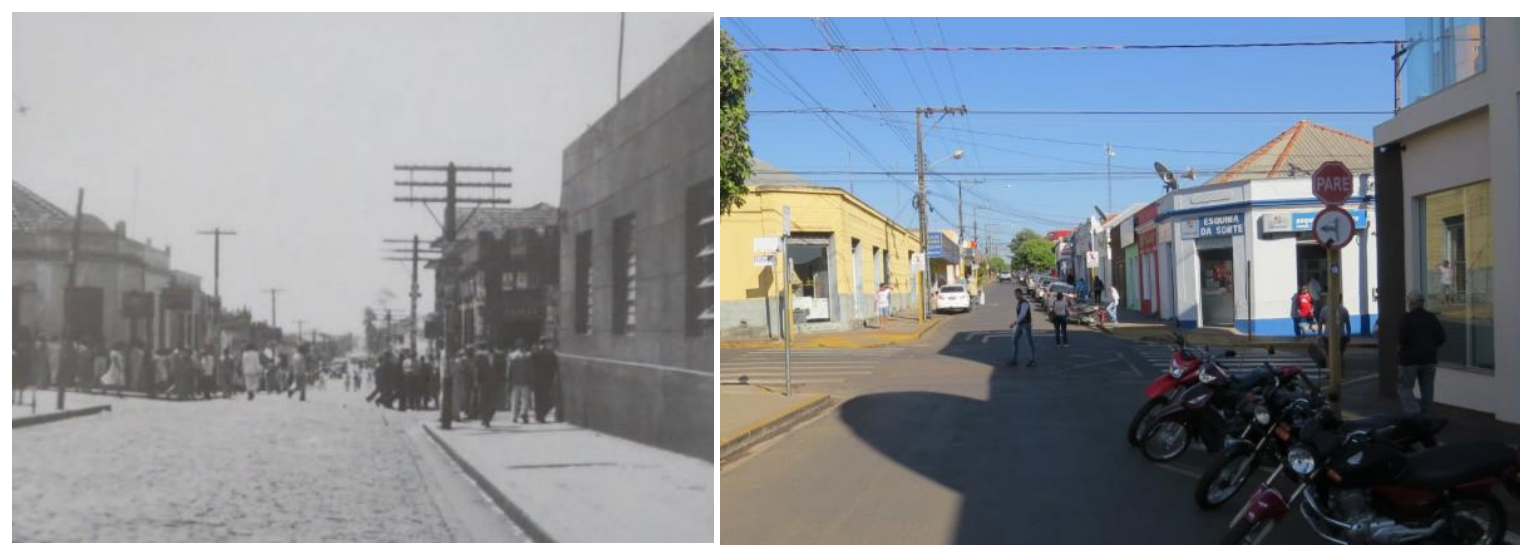

Figura 5. Rua 9 de Julho esquina com a Rua Tenente Casemiro Dias, em 1940 e atualmente. Fonte: Daltozo (2004) e Autora.
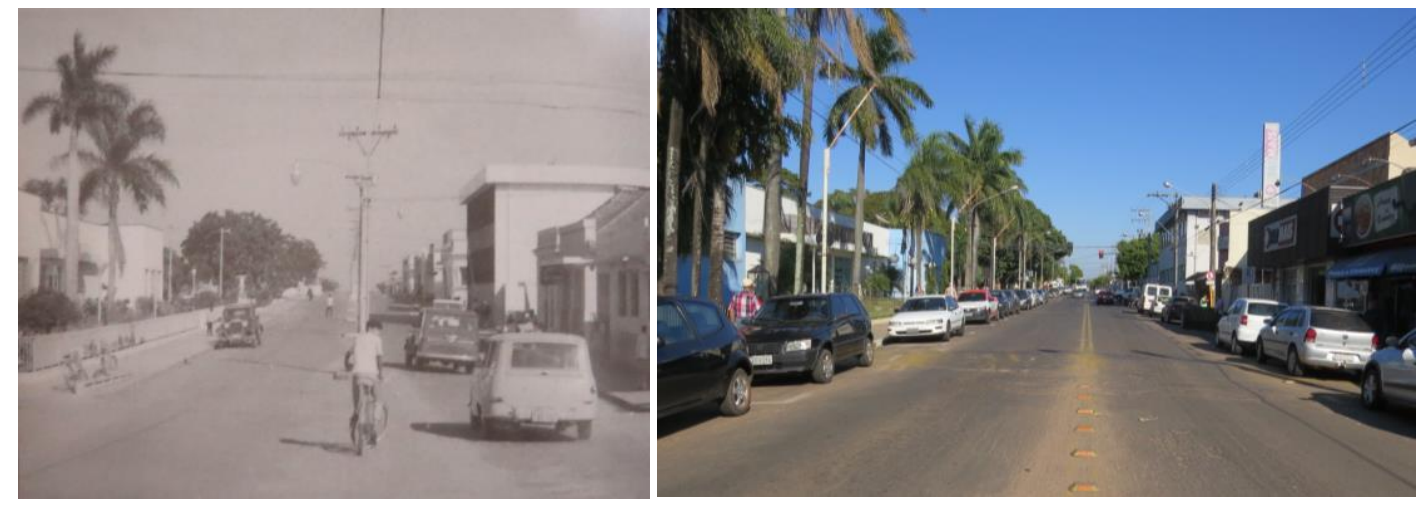

Figura 06. Av. João Gomes Martins em 1960 e atualmente, a esquerda está o edifício da Prefeitura.

Fonte: Daltozo (2004) e Autora.

Em Indiana a estação ferroviária foi inaugurada em 1917 (Quadro 1), e possuia movimento razoável em função do pouso de gado e da chegada de agricultores, fazendeiros e comerciantes que queriam comprar terras. O traçado da cidade não é diferente das demais da Alta Sorocabana, já que segue o padrão da malha ortogonal em tabuleiro xadrez. Como cresceu a partir dos trilhos e da Estação Ferroviária, estabelece uma relação com esses elementos, o traçado segue a linha férrea, que não é totalmente retilínea, por isso, algumas quadras possuem forma triangular ou trapezoidal, se adequando a essa proximidade.

A partir dos mapas obtidos e de demais informações encontradas foi elaborado um mapa com o redesenho do suposto núcleo urbano original da cidade (Figura 7), não foram encontrados documentos que confirmassem a área ou o perímetro desse possível núcleo, portanto, com o material disponível deduziu-se essa extensão. 


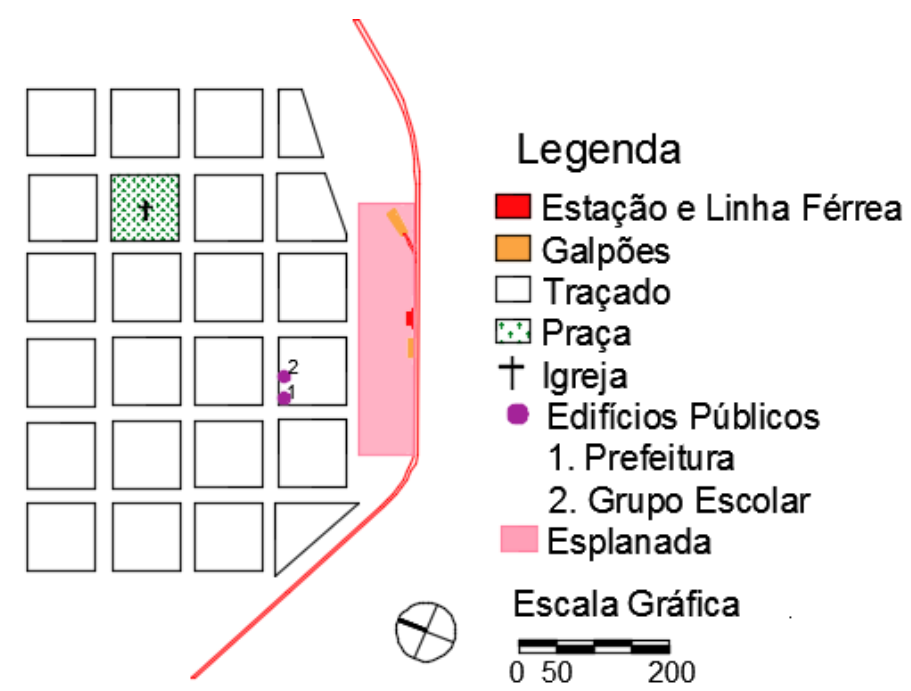

Figura 07. Núcleo Urbano Original de Indiana, ano desconhecido.

Fonte: Arquivo Público do Estado de São Paulo, redesenhado pela autora.

A cidade pouco cresceu ao longo do tempo e, por isso, há um predomínio do traçado do núcleo urbano original, visto que em sua expansão houve uma repetição da quadrícula (Figura 8). As quadras mais próximas a linha férrea foram modificadas, e não apresentam mais a dimensão e forma originais, analisando os mapas supõe-se que isso aconteceu após a ocupação da esplanada.
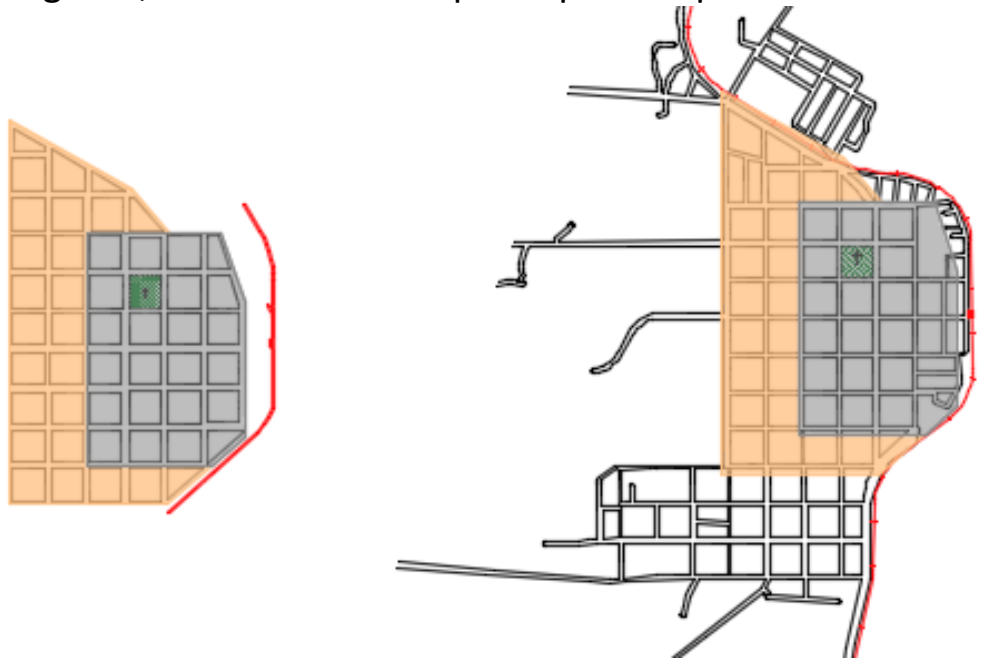

\section{Legenda \\ Estação e Linha Férrea Núcleo Urbano Original $\square$ Expansão}

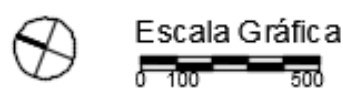

Figura 08. Esquema de Crescimento de Indiana.

Fonte: Arquivo Público do Estado de São Paulo e Google Earth, redesenhado pela autora.

A esplanada de Indiana era ocupada inicialmente pelas residências de funcionários que trabalhavam na ferrovia, dois galpões da companhia Estrada de Ferro Sorocabana, e algumas instalações hidráulicas, incluindo uma caixa d'água (Figura 9). Existiam tipologias diferentes das residências e algumas dessas apresentaram pequenas alterações ao longo do tempo. Havia ainda outras residências na parte posterior da ferrovia em relação a cidade, uma delas se encontra até hoje na cidade. 


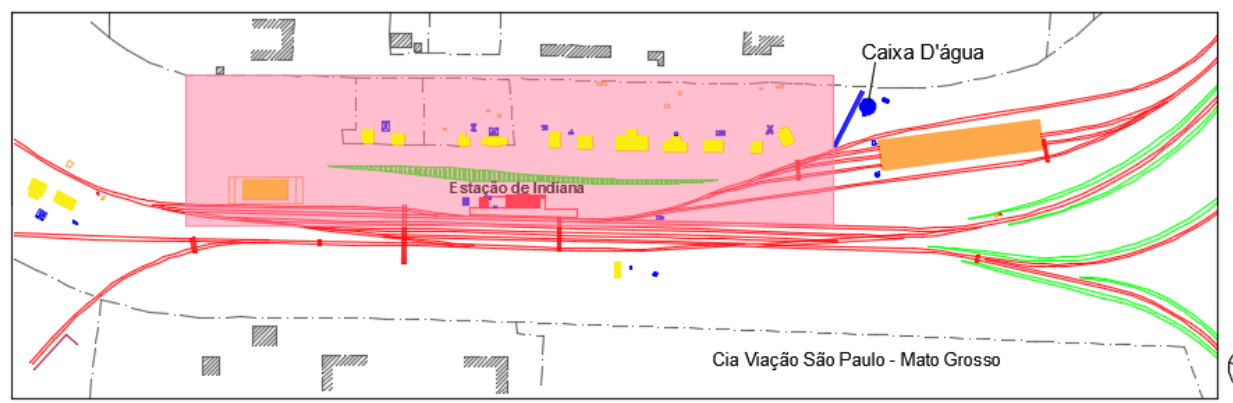

Legenda

Estação e Linha Férrea

$\square$ Galpões

$\square$ Residências

Talude

Instalações Hidráulicas

$\square$ Esplanada

EscalaGráfica

Figura 09. Mapa da Esplanada de Indiana, ano desconhecido.

Fonte: Escritório da Inventariança da Rede Ferroviária Federal S.A. de São Paulo, redesenhado pela autora.

Atualmente, a esplanada encontra-se ocupada por residências de dois conjuntos habitacionais da CDHU, que foram construídos em 1989 e em 1992 (Figura 10). Portanto, as antigas residências dos funcionários da ferrovia foram demolidas para a construção dessas novas habitações. Além das residências, o maior galpão também foi demolido, e sua área foi ocupada por edificações.

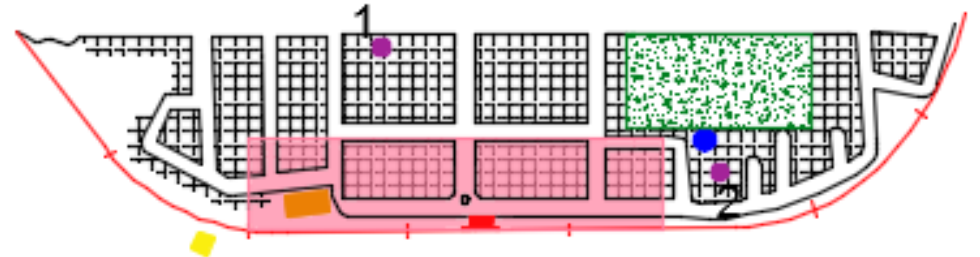

$\otimes$
Legenda

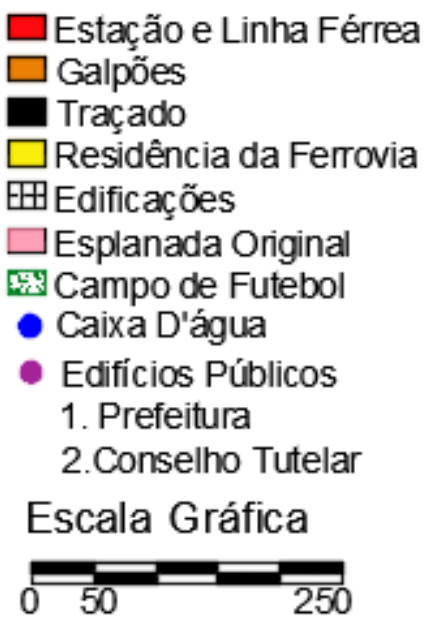

Figura 10. Mapa da Esplanada de Indiana atualmente.

Fonte: Google Earth, redesenhado pela Autora.

O aspecto visual do que restou do patrimônio ferroviário não sofreu grandes transformações, a grande mudança ocorreu em relação ao uso das edificações. A Estação Ferroviária (Figura 11) hoje serve como residência para um funcionário da prefeitura, assim como o antigo prédio do grupo escolar que hoje abriga o Paço Municipal (Figura 12), este que antigamente localizava-se ao lado de seu local atual, e hoje seu espaço é utilizado como depósito.
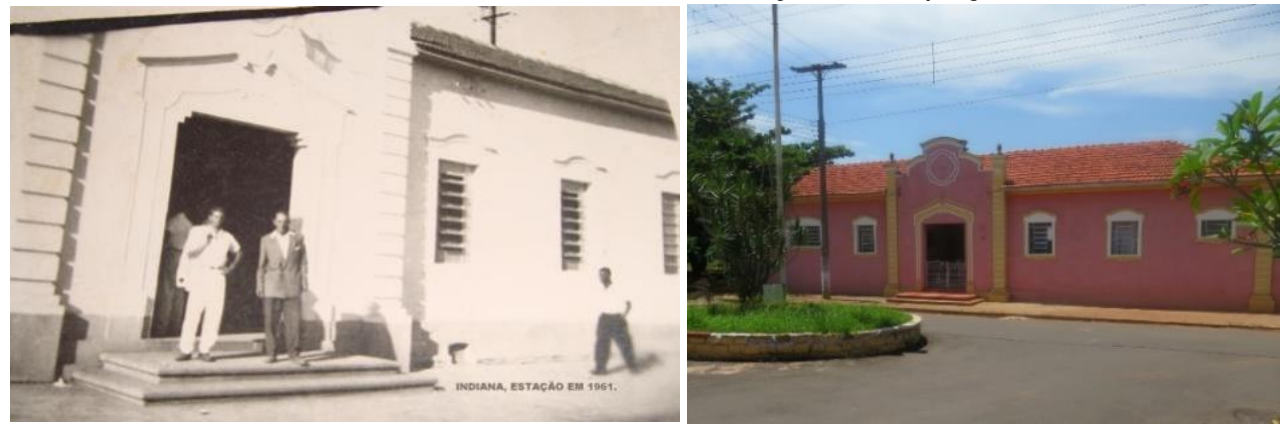

Figura 11. Estação Ferroviária Indiana em 1961 e atualmente.

Fonte: Prefeitura de Indiana e Autora. 

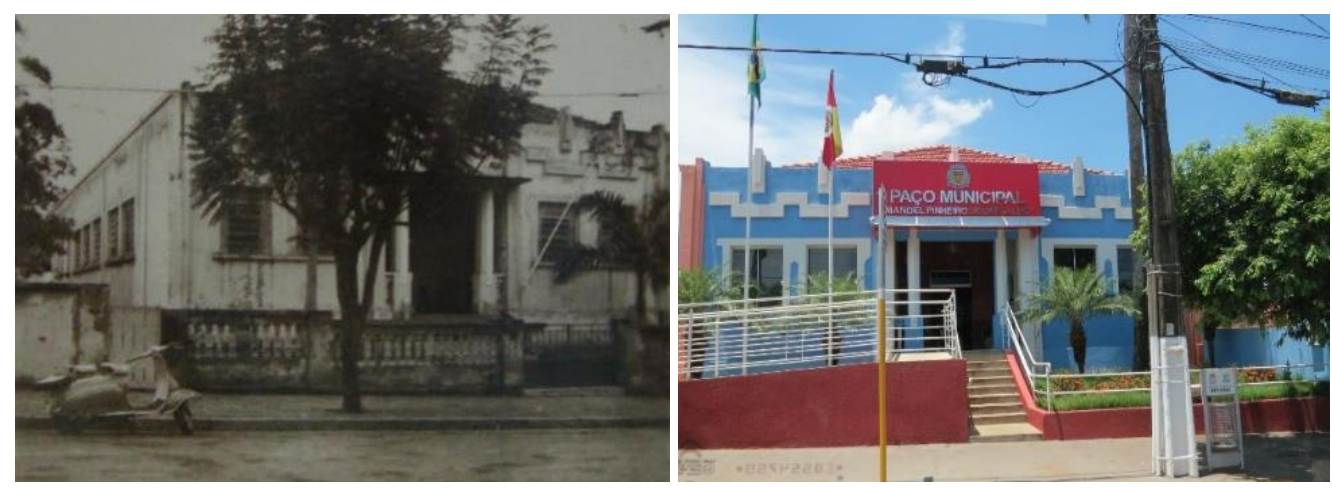

Figura 12. Prédio do Antigo Grupo Escolar, 1955, e Atual Paço Municipal.

Fonte: Prefeitura de Indiana e Autora.

Quadro 01. Informações Gerais das Cidades.

\begin{tabular}{|c|c|c|c|}
\hline Cidade & $\begin{array}{c}\text { Estação/ } \\
\text { Patrimônio }\end{array}$ & Fazenda & Município \\
\hline Martinópolis & $\begin{array}{c}\text { José Teodoro } \\
1917\end{array}$ & $\begin{array}{c}\text { Fazenda Boa } \\
\text { Ventura }\end{array}$ & $\begin{array}{c}\text { Martinópolis } \\
29 \text { de Janeiro de } \\
1939-\text { Lei no } 9775\end{array}$ \\
\cline { 2 - 4 } & $\begin{array}{c}\text { José Teodoro } \\
1924\end{array}$ & & $\begin{array}{c}\text { Indiana } \\
\text { Indiana }\end{array}$ \\
& Indiana & Fazenda Indiana & 24 de Dezembro de \\
& 1917 & & 1948 - Lei № 233 \\
\cline { 2 - 4 } & Indiana & & \\
\hline
\end{tabular}

Fonte: IBGE, EMUBRA, Daltozo, Fabri, Estações Ferroviárias, Prefeituras de Indiana e Martinópolis, elaborado pela autora.

\section{DISCUSSÃO}

A Estrada de Ferro Sorocabana e a ação dos latifundiários deram às futuras cidades, características semelhantes na implantação de seus traçados. A construção da ferrovia ao longo do espigão formado entre os rios Peixe e Paranapanema mudou as formas dos traçados urbanos, que foram desenhados em tabuleiro xadrez, estabelecidos em terras planas, antes mesmo da ocupação. O relevo da região influenciou na repetição dos planos na cidade (Francisco, 2015). Além disso, essas cidades foram feitas por agrimensores que optaram por usar a retícula perfeita, devido a facilidade de execução.

Martinópolis e Indiana possuem a mesma tipologia de traçado, em tabuleiro xadrez, com quadras de 80x80 metros em Martinópolis e 90x90 metros em Indiana. O desenho urbano das cidades formadas após a instalação da Estrada de Ferro Sorocabana foi orientado pelos trilhos, Martinópolis e Indiana se organizaram a partir da estação, esplanada e linha férrea, nestas cidades inexistiu o antigo sistema de formação urbana a partir do patrimônio religioso, ou seja, das terras doadas à Igreja.

O arruamento foi feito, inicialmente, apenas de um lado, a frente da estação, somente em Martinópolis foi feito um loteamento "do outro lado da linha", após alguns anos, em 1938, dando origem a Vila Alegrete. A Igreja Matriz dessas cidades localiza-se deslocada do eixo perpendicular da estação - em Martinópolis, foi construída, alguns anos depois, no cruzamento das duas avenidas presentes no núcleo urbano original; já em Indiana localiza-se em uma quadra na área central.

As esplanadas dessas cidades apresentam configuração semelhante, com as residências de funcionários e galpões, que em conjunto com as indústrias localizavam-se ao longo da linha férrea pois utilizavam o transporte ferroviário. 


\section{CONCLUSÃO}

Não havia preocupação estética e urbanística nos desenhos dos núcleos urbanos de Martinópolis e Indiana, o traçado geométrico era independente das condições do relevo e se adequava ao desejo do loteador, já que era fácil de realizar a continuação das ruas, caso o núcleo se desenvolvesse.

Em Indiana não houve preocupação com a conservação das construções relacionadas a ferrovia, apenas a estação, que hoje é usada como moradia por um funcionário da prefeitura, como meio de conserva-la. A caixa d'água, uma residência, que se encontra escondida em meio ao matagal, e um galpão, que está em desuso, permaneceram. Em Martinópolis, essa preocupação é maior, já que a estação e os galpões foram restaurados e hoje apresentam funções culturais, e, ainda, permaneceram algumas residências de antigos funcionários da companhia ferroviária, sendo que algumas continuaram com suas funções residenciais e outras passaram a servir a administração da cidade.

\section{REFERÊNCIAS}

ABREU, D. S. Formação histórica de uma cidade pioneira paulista. Presidente Prudente: Faculdade de Filosofia, Ciências e Letras de Presidente Prudente, 1972.

DALTOZO, J. C. Álbum histórico e fotográfico de Martinópolis. Martinópolis: Gráfica Martipel Ind. e Com. Ltda, 2004.

. Martinópolis, sua história e sua gente. Martinópolis: Gráfica Martipel Ind. e Com. Ltda, 1999.

. Nos Trilhos da História - A estrada de Ferra Sorocabana em Martinópolis - 90 anos 1917-2007. Presidente Prudente: Impress Gráfica e Editora, 2007.

DEL RIO, V. Introdução ao Desenho Urbano no Processo de Planejamento. S. Paulo: Pini, 1990.

ENCICLOPÉDIA dos Municípios Brasileiros. Presidente Prudente: EMUBRA, 2003.

FRANCISCO, A. M. A EFS como linha de penetração para a ocupação da Alta Sorocabana (mimeo), 2015.

IBGE, Instituto Brasileiro de Geografia e Estátistica, 2016.

LAMAS, J. Morfologia Urbana e Desenho da Cidade. Fundação Calouste Gulbenkian, 1993.

PANERAI, P. Análise Urbana. Editora UnB, 2006. 